\title{
Pendeteksian Lokasi Sumber Noise (Partial Discharge) secara Tiga Dimensi menggunakan Antenna Array
}

\author{
NUR IBRAHIM \\ Teknik Telekomunikasi Universitas Telkom \\ Email: nuribrahim@telkomuniversity.ac.id
}

\begin{abstract}
ABSTRAK
Pada penelitian ini akan dilakukan simulasi teknik pendeteksian lokasi sumber noise berupa partial discharge (PD) pada peralatan tegangan tinggi, dengan menggunakan susunan antena yang terdiri dari empat buah antena monopole sebagai sensor untuk mendeteksi gelombang elektromagnetik (EM) yang dipancarkan dari partial discharge (PD). Algoritma yang digunakan mengacu kepada time difference of arrival (TDOA) dari sinyal yang diterima antar antena (dengan menjadikan salah satu antena sebagai antena referensi). Metode yang digunakan untuk menentukan TDOA adalah metode Akaike Information Criterion, metode Energy Criterion, metode Gabor Centroid, metode threshold detection, metode peak detection, dan metode cross-correlation. Sistem pendeteksian lokasi sumber noise ini menggunakan konfigurasi susunan antena membentuk $Y$. Jarak antar antena diatur sejauh 2 meter dan 4 meter. Berdasarkan hasil pengamatan dan analisis, konfigurasi susunan antena membentuk $Y$ memiliki tingkat akurasi 97.67\%. Metode yang paling akurat untuk menentukan TDOA adalah metode cross-correlation.
\end{abstract}

Kata kunci: PD, TDOA, susunan antena.

\begin{abstract}
This paper presents a simulation of locating noise source (Partial Discharge) on high-voltage apparatuses, by using antenna array that consisted of four monopole antennas as sensor to record the electromagnetic waves (EM) emitted from Partial Discharge (PD). The detection algorithm is based on the time difference of arrival (TDOA) of the signals received between antennas (by using one of four antennas as reference antenna). The methods to determine TDOAs are Akaike Information Criterion method, Energy Criterion method, Gabor Centroid method, threshold detection method, peak detection method, and/or cross-correlation method. These system use Y-shaped array configuration. The adjusted distance between antennas are 2 meter and 4 meter. From the observation and analysis results, $Y$-shaped array antenna configuration has accuracy $97.76 \%$. The best method to get TDOA is the cross-correlation method.
\end{abstract}

Keywords: PD, TDOA, antenna array. 


\section{PENDAhULUAN}

Partial Discharge (PD) adalah salah satu sumber noise impulsif broadband yang mengakibatkan interferensi gelombang elektromagnetik (EM) pada televisi dan siaran radio. PD yang berasal dari cacat pada sistem perkabelan dan peralatan pembangkit listrik bertegangan tinggi dapat menjadi sumber noise yang berkesinambungan untuk seluruh lingkungan. sedangkan noise yang timbul pada vehicle ignition system, microwave ovens, dan sistem lainnya, hanya bersifat sementara. Selain itu, spektrum frekuensi noise impulsif dari kabel pembangkit listrik, sebagian besar berada pada rentang nilai puluhan hingga ratusan megahertz (Steiner, 1992; Quak, 2003).

Untuk mendapatkan lingkungan dengan EM yang lebih baik,dibutuhkan cara untuk menemukan lokasi sumber noise impulsif tersebut. Dengan menemukan lokasi sumber noise tersebut, dapat dilakukan tindakan yang tepat untuk menghilangkan sumber noise tersebut. Teknik untuk mencari lokasi noise EM yang berasal dari muatan listrik, telah dijelaskan 50 tahun yang lalu (Kreuger, 1964) dengan menggunakan pengukuran dari fenomena gelombang elektromagnetik berjalan. Beberapa penelitian telah mengenalkan teknik menentukan lokasi sumber noise dengan akurasi dan sensitivitas yang lebih baik (Steiner, 1992; Quak, 2003; Mashikian, 2002).

Pada pembangkit listrik, relatif telah ada kemajuan pada sistem mencari lokasi sumber noise, dimana secara umum, telah dapat diaplikasikan dalam suatu lingkup kecil dari pembangkit listrik, dibandingkan sistem sebelumnya yang diaplikasikan pada sebuah komponen di pembangkit listrik. Dalam konteks ini, penggunaan frekuensi untuk penginderaan jarak jauh, memegang peranan penting karena mudah diinstalasi, tidak membutuhkan kontak langsung serta dapat diaplikasikan kepada semua komponen bermuatan pada pembangkit listrik.

Dalam penelitian ini akan dikembangkan metode pendeteksian lokasi sumber noise impulsif (dalam bentuk tiga dimensi) dengan menggunakan antenna array (Mashikian, 2002). Antenna array ini terdiri dari empat buah antena monopole. Algoritma lokalisasi didasarkan pada TDOA dari pulsa EM yang diterima antena-antena yang terpisah secara spasial. TDOA dapat ditentukan dengan menggunakan beberapa metode, yaitu metode Akaike Information Criterion, metode Energy Criterion, metode Gabor Centroid, metode threshold detection, metode peak detection, dan metode cross-correlation (Knapp, 1976).

Challa dan Shamsunder (Challa, 1998) mengusulkan pendekatan subspace resolusi tinggi untuk lokalisasi sumber EM medan dekat (near-field) dalam bentuk three-dimensional space. Namun, pendekatan ini terbatas pada lokalisasi sumber dengan band yang sempit (narrowband). Peck dan Moore (Tungkanawanich, 2001) menunjukkan penerapan algoritma HT (Knapp, 1976) untuk estimasi TDOA. Hal ini menunjukkan peningkatan performansi dari estimasi direction-of-arrival(DOA). Pada penelitian sebelumnya, estimasi untuk sumber noise ini kebanyakan fokus pada pengukuran, dengan teori sederhana. Pada model teoritis, gelombang datar dianggap sebagai sumber gelombang. Dengan kata lain, medan EM yang dipancarkan dari sumber noise impulsif diasumsikan sebagai medan jauh (far-fields). Namun, magnitude dari gelombang EM yang dipancarkan dari kabel transmisi dan peralatan pembangkit listrik tidak besar. Dengan demikian, jarak antara antena dan sumber noise terbatas hanya maksimal sejauh beberapa puluh meter. Inilah alasan utama pendekatan medan dekat (near-field) akan lebih tepat, dan oleh karena itu, skema lokalisasi secara tiga dimensi untuk sumber noise broadband dapat direalisasikan. 
Dengan antenna array dan metode yang digunakan pada penelitian ini, lokasi sumber noise impulsif dapat ditemukan dari jarak jauh tanpa harus kontak langsung ke area pembangkit listrik, dengan tingkat akurasi yang tinggi.

\section{METODOLOGI}

\subsection{Radiasi Impulsif}

Initial rise-time dari current waveform yang dihasilkan dari partial discharge (PD) akan menyebabkan peluang terjadinya pelebaran spektrum frekuensi menjadi ke dalam region frekuensi radio. Konsekuensi dari fenomena ini adalah, sebagian energi dari PD akan teradiasi ke ruang hampa udara, sehingga PD dapat dideteksi posisinya menggunakan radiometry.

Telah banyak dilakukan pengukuran radiometric menggunakan peralatan penerima radio narrowband down-converting. Seiring dengan pengembangan pada teknologi digital sampling saat ini, memungkinkan untuk merekam waveform dari radiasi PD dengan resolusi tinggi (Cavallini, 2003). Pengukuran ini memiliki beberapa karakteristik, antara lain:

\section{a. Directly-sampled}

Sinyal yang diterima antena, langsung di-sampling, tanpa di-down-converted terlebih dahulu, sehingga terjadi peningkatan dalam validasi sinyal.

b. Wideband

Lebar pita analog berada pada rentang $1 \mathrm{GHz}$, dengan frekuensi sampling dalam rentang Giga-Samples per detik.

Hasil dari pengukuran yang dilakukan dengan teknologi digital ini adalah berupa wideband, radiative partial discharge (WRPD) waveforms. Jika dibandingkan dengan pengukuran konfensional, WRPD waveforms ini menunjukkan peningkatan dalam konten informasi.

\subsection{Karakteristik Lingkungan Gardu}

Bahan metal di sekitar sumber PD dan antena penerima akan mempengaruhi karakteristik sinyal WRPD yang disebabkan dari scattering dan reflection. Reflection menyebabkan multipath propagation impulse WRPD dan hasil pengukuran sinyal di antena merupakan penjumlahan direct-path signal dari PD ke antena, dan beberapa sinyal yang direfleksikan. Karena banyaknya permukaan dan benda yang dapat merefleksikan sinyal pada lingkungan gardu, karakteristik dari bentuk gelombang WRPD lebih banyak dipengaruhi oleh lingkungan sekitar dan posisi pengukuran, dibandingkan dengan sifat dielektrik yang menyebabkan PD.

\subsection{Prinsip Dasar}

Pada bagian sebelumnya telah ditegaskan bahwa lingkungan propagasi memiliki dampak terbesar pada bentuk gelombang WRPD. Meskipun demikian, lokasi sumber PD dapat ditemukan dengan menganalisis bagian awal dari gelombang WRPD yang merepresentasikan direct-path signa/ dari sumber PD sebelum terjadi refleksi. Setelah gelombang langsung, efek pantulan akan menyebabkan perbedaan bentuk sinyal yang diterima (ini adalah multipath region).

Pendeteksian lokasi sumber noise secara tiga dimensi dapat ditentukan dengan menggunakan antenna array pasif yang terdiri dari empat buah antena monopole. Pandangan konseptual dari proses ini dapat dilihat pada Gambar 1. Empat buah antena disusun membentuk $Y$ dengan jarak antar antena $d$. Lokasi sumber noise $P$ diasumsikan sebagai variabel yang belum diketahui $[x, y, z]$. Empat buah antena diberi label $1,2,3$, dan 
4, serta koordinat masing-masing antena adalah $[x 1, y 1,1],[x 2, y 2,1],[x 3, y 3,1]$, dan $[x 4$, $y 4,1]$ meter. Perlu dicatat bahwa tiga nilai TDOA yang independen, dapat diperoleh dari keempat konfigurasi antena ini. Sinyal yang diterima oleh antena 1 (berada di tengah, dengan koordinat $[0,0,1]$ ) dipilih sebagai sinyal referensi. Hubungan antara koordinat antena dan TDOA adalah persamaan non-linier sebagai berikut:

$$
\begin{aligned}
& c . \Delta t_{12}=\sqrt{\left(x-x_{2}\right)^{2}+\left(y-y_{2}\right)^{2}+\left(z-z_{2}\right)^{2}}-\sqrt{\left(x-x_{1}\right)^{2}+\left(y-y_{1}\right)^{2}+\left(z-z_{1}\right)^{2}} \\
& c . \Delta t_{13}=\sqrt{\left(x-x_{3}\right)^{2}+\left(y-y_{3}\right)^{2}+\left(z-z_{3}\right)^{2}}-\sqrt{\left(x-x_{1}\right)^{2}+\left(y-y_{1}\right)^{2}+\left(z-z_{1}\right)^{2}} \\
& c . \Delta t_{14}=\sqrt{\left(x-x_{4}\right)^{2}+\left(y-y_{4}\right)^{2}+\left(z-z_{4}\right)^{2}}-\sqrt{\left(x-x_{1}\right)^{2}+\left(y-y_{1}\right)^{2}+\left(z-z_{1}\right)^{2}}
\end{aligned}
$$

dimana $\Delta t_{i j}$ menunjukkan TDOA antara antena $i$ dengan antena $j$, dan $c$ adalah kecepatan gelombang elektromagnetik di ruang hampa udara $\left(c=3 \times 10^{8} \mathrm{~m} / \mathrm{sec}\right)$. Lokasi sumber noise $P[x, y, z]$ dapat diperkirakan jika semua nilai TDOA diperoleh. Solusi persamaan non-linier diatas dapat diperoleh dengan menggunakan teknik iterasi Newton-Raphson.

Gambar 1 menunjukkan gambaran geometri dari susunan antena membentuk $Y$ dan lokasi sumber noise secara tiga dimensi.

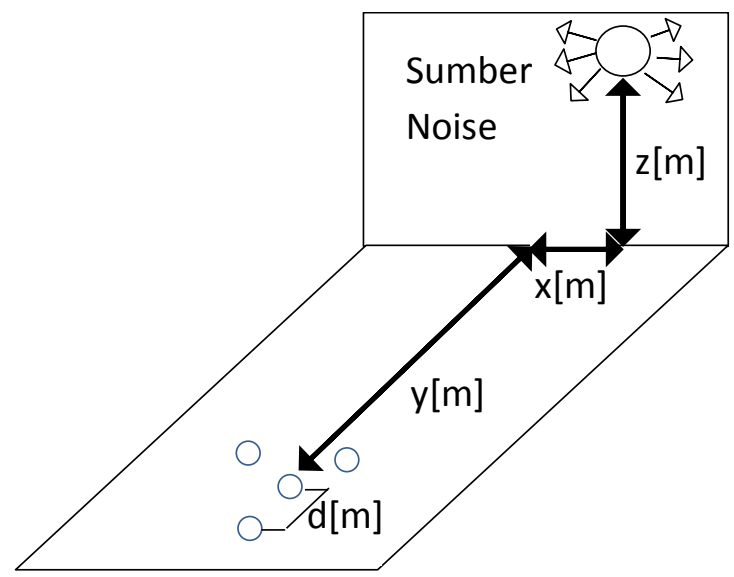

Gambar 1. Geometri dari metoda pendeteksian lokasi secara tiga dimensi

\subsection{Model Sinyal Sumber Noise}

Sinyal sumber noise dari PD dimodelkan dengan persamaan berikut:

$$
S(t)=A_{0} \sin (2 \pi f t)\left(-\exp \left(-\frac{t}{\tau_{1}}\right)+\exp \left(-\frac{t}{\tau_{2}}\right)\right)
$$

Parameter dari model sumber noise (persamaan 4) adalah seperti pada Tabel 1 berikut ini: 
Tabel 1. Parameter model sumber noise

\begin{tabular}{|c|c|c|c|c|}
\hline $\boldsymbol{A}_{\mathbf{0}}$ & $\tau_{\mathbf{1}}$ (ns) & $\tau_{\mathbf{2}}$ (ns) & $\boldsymbol{c}(\mathbf{m} / \mathbf{s})$ & $\boldsymbol{f} \mathbf{( M H z})$ \\
\hline 2.6 & 40 & 50 & $3 \times 10^{8}$ & 50 \\
\hline
\end{tabular}

Gambar 2 menunjukkan model sinyal sumber noise untuk periode 1 microsecond. Pada simulasi yang dijalankan, ditambahkan noise Gaussian dengan signal-to-noise ratio (SNR) sebesar $10 \mathrm{~dB}$ pada model sumber sinyal (Oussalah, 2007). Perlu dicatat bahwa perhatian lebih dilakukan pada pita frekuensi antara 25 dan $150 \mathrm{MHz}$, dimana pada pita frekuensi tersebut mayoritas terjadi sinyal PD. Pada pita frekuensi ini, siaran radio FM dioperasikan.

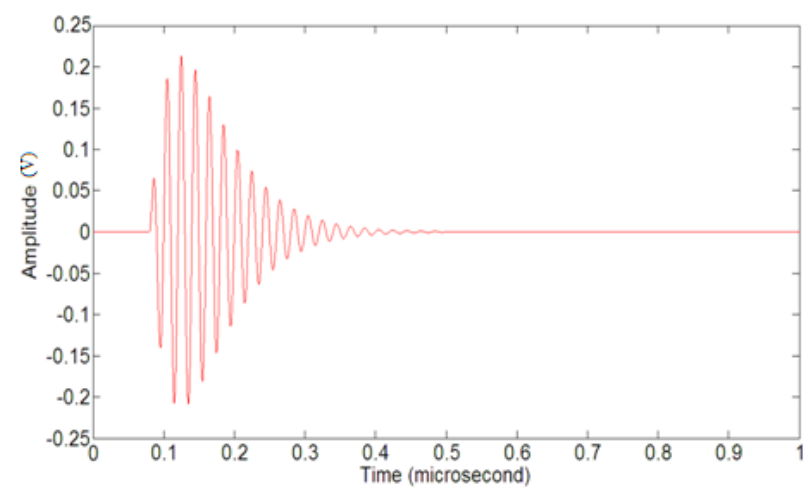

Gambar 2. Bentuk gelombang dari model sinyal sumber noise

\subsection{Estimasi TDOA}

\section{Metode Akaike Information Criterion}

Akaike Information Criterion (AIC) adalah ukuran kebaikan fit dari model statistic untuk satu set pengamatan. Metode ini dapat digunakan untuk mengestimasi Time Of Arrival (TOA) sinyal PD yang diterima pada masing-masing antena, sehingga didapatkan empat nilai TOA.

Persamaan (5)mendefinisikan kurva $\mathrm{AIC}_{\mathrm{k}}$ :

$$
A I C_{K}=k \cdot \ln \left(\sigma_{1, k}^{2}\right)+(N-k-1) \cdot \ln \left(\sigma_{k+1, N}^{2}\right)
$$

dimana $\sigma_{k+1, N}^{2}$ adalah nilai variance sinyal $S_{k}$ (sinyal yang diterima antena, dengan $k$ adalah nilai indeks dari 1 hingga $M$. $N$ adalah jumlah sampel sinyal. Nilai $A I C_{K}$ dihitung untuk tiap sampel pada sinyal $S_{k}$. TOA adalah nilai minimum dari keseluruhan nilai $A I C_{K}$. Untuk mencegah hasil yang ambigu, sinyal dipotong sedemikian rupa sehingga pulsa onset terjadi pada pertengahan sinyal, seperti yang disarankan oleh Tungkanawanich (Tungkanawanich, 2001). 


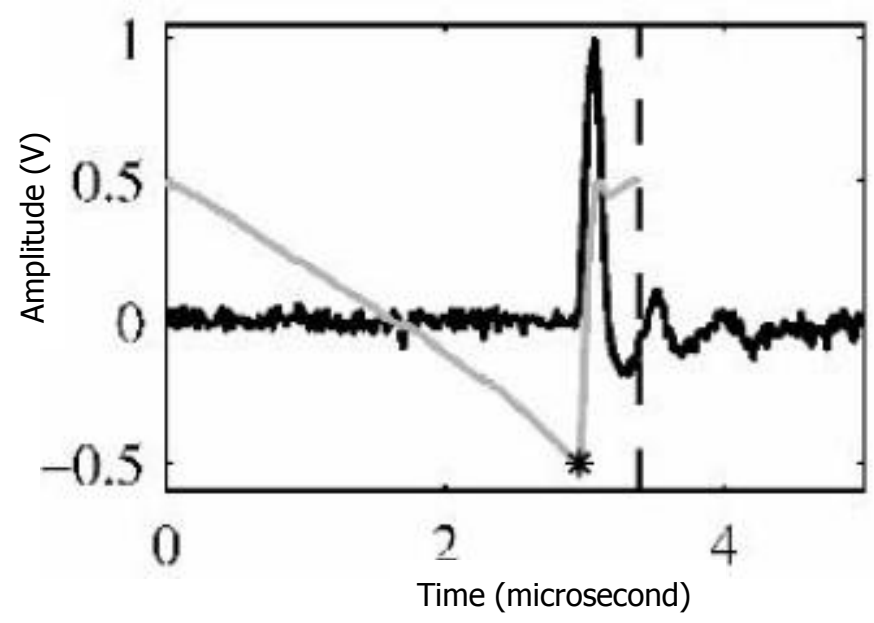

Gambar 3. Contoh sinyal PD dengan mengaplikasikan metoda AIC untuk menentukan TOA (Wagenaars, 2008)

Gambar 3 menunjukkan hubungan antara sinyal PD (kurva yang berwarna hitam) dan AIC (kurva yang berwarna abu-abu) yang telah digeser dan dinormalisasi. Waktu (time) saat nilai amplituda pada kurva AIC bernilai minimum, yang diambil sebagai nilai TOA (ditandai dengan tanda * pada kurva AIC).

Dengan menjadikan antena satu sebagai antena acuan, maka didapatkan tiga nilai TDOA dengan mencari selisih antara masing-masing TOA dengan TOA antena 1. Persamaan (6), (7), dan (8) menunjukkan persamaan matematis untuk mendapatkan nilai TDOA

$$
\begin{aligned}
& T D O A_{12}=T O A_{2}-T O A_{1} \\
& T D O A_{13}=T O A_{3}-T O A_{1} \\
& T D O A_{14}=T O A_{4}-T O A_{1}
\end{aligned}
$$

Dimana $\mathrm{TOA}_{1}$ adalah TOA pada antena $1, \mathrm{TOA}_{2}$ adalah TOA pada antena $2, \mathrm{TOA}_{3}$ adalah TOA pada antena 3 , dan $\mathrm{TOA}_{4}$ adalah TOA pada antena 4. TDOA 12 adalah TDOA antara antena 2 dengan antena 1, TDOA ${ }_{13}$ adalah TDOA antara antena 3 dengan antena 1, dan TDOA 14 adalah TDOA antara antena 4 dengan antena 1 . Ketiga nilai TDOA yang didapat dari persamaan (6), (7), dan (8) akan dimasukkan ke persamaan (1), (2), dan (3), sehingga akan didapatkan nilai koordinat lokasi sumber noise.

\section{Metode Energy Criterion}

Metode Energy Criterion (EC) menggunakan energi yang terkandung pada sinyal. Metode ini menggabungkan energi sinyal parsial dengan tren negatif (Challa, 2008).

Sinyal $E C_{K}$ didefinisikan dengan persamaan (9) berikut:

$$
E C_{K}=\sum_{i=1}^{k} s_{i}^{2}-k \cdot P_{S}
$$

dimana $P_{s}$ adalah mean power dari $s_{k}$. Nilai $E C_{K}$ dihitung untuk ranging $k$ dari 1 sampai $N$. Nilai minimum dari keseluruhan nilai $E C_{K}$ adalah TOA. 


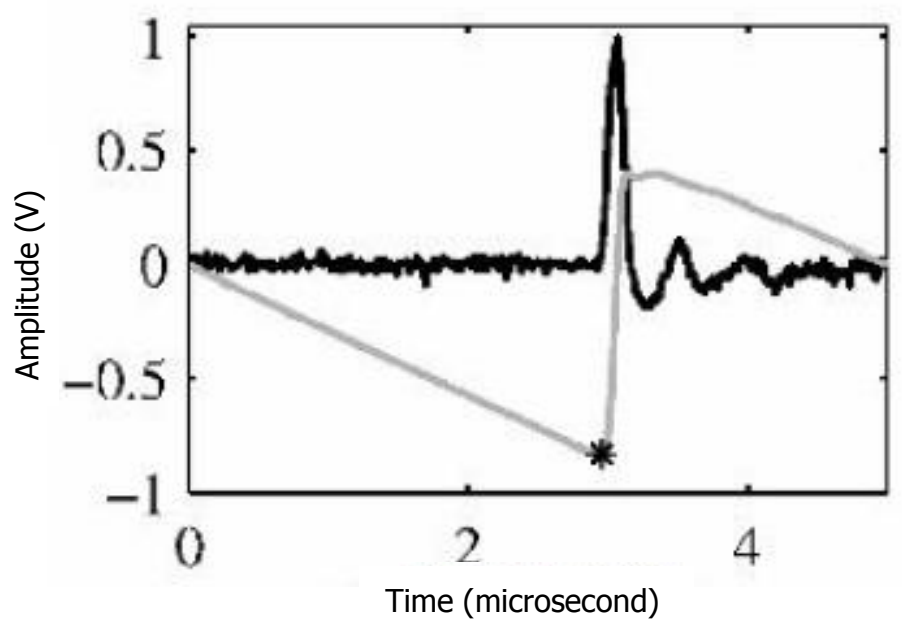

Gambar 4. Contoh sinyal PD dengan mengaplikasikan metoda EC untuk menentukan TOA (Wagenaars, 2008)

Gambar 4 menunjukkan hubungan antara sinyal PD (kurva yang berwarna hitam) dan EC (kurva yang berwarna abu-abu) yang telah digeser dan dinormalisasi. Waktu (time) saat nilai amplituda pada kurva EC bernilai minimum, itulah yang diambil sebagai nilai TOA (ditandai dengan tanda * pada kurva EC).

\section{Metode Gabor Centroid}

Gabor mendefinisikan "waktu" orde 1 dari sinyal (Mardiana, 2000). Dengan mengasumsikan bahwa sinyal tersebut adalah real, kemudian mengkonversinya menjadi bentuk time-discrete dan menambahkan dua persamaan untuk menghilangkan noisedependency, maka "waktu" ini didefinisikan seperti ditunjukkan pada persamaan (10) :

$$
T O A_{g}=\frac{\sum_{k=1}^{N} t_{k} s_{k}^{2}-P_{n} \sum_{k=1}^{N} t_{k}}{\sum_{k=1}^{N} s_{k}^{2}-P_{n} \cdot N}
$$

$t_{k}$ adalah nilai waktu yang menyesuaikan dengan indeks k. $P_{n}$ adalah mean power dari $n_{k}$.

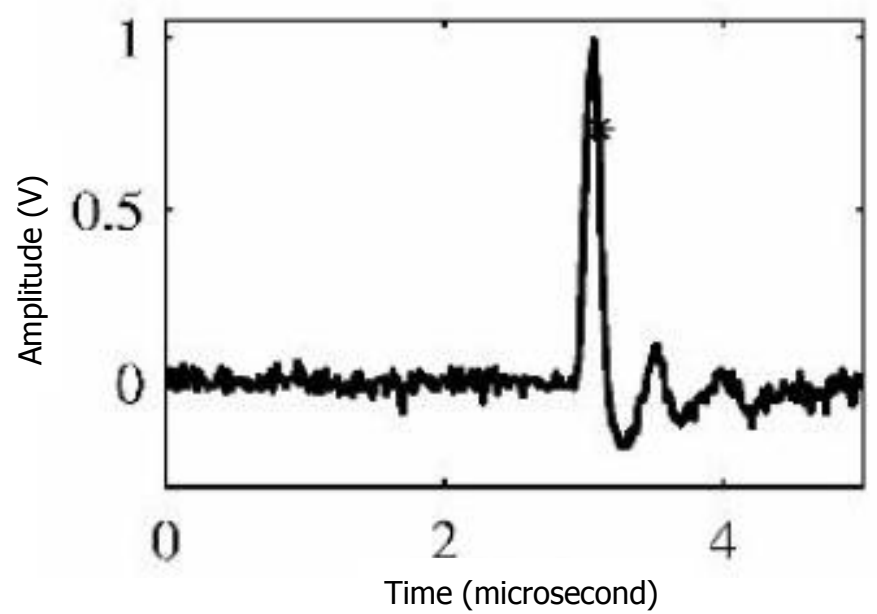

Gambar 5. Contoh sinyal PD dengan mengaplikasikan metoda Gabor Centroid untuk menentukan TOA (Wagenaars, 2008) 
Gambar 5 menunjukkan sinyal PD yang akan diproses menggunakan persamaan (10), sehingga didapatkan nilai TOA, dimana posisi nilai TOA hasil dari persamaan (10) ditunjukkan dengan tanda * pada Gambar 5.

\section{Metode Threshold Detection}

Metode threshold detection mendefinisikan nilai TOA pada saat sinyal $s_{k}$ melebihi nilai ambang batas tertentu $s_{\text {thres }}$. Ini adalah metode langsung yang dapat diimplementasikan dengan mudah sehingga telah gunakan pada banyak sistem deteksi PD.

Nilai ambang batas dipilih relatif terhadap tingkat kebisingan, sehingga nilai ambang batas akan selalu bernilai rendah, sesuai dengan tingkat kebisingan yang diperbolehkan, tanpa terlalu banyak false trigger. Berikut ini adalah persamaan untuk menentukan nilai ambang batas :

$$
s_{\text {thres }}=m \cdot \sqrt{P_{n}}
$$

dimana $m$ adalah nilai parameter yang dipilih oleh user. Pada penelitian ini, digunakan nilai $m=5$ untuk mengatasi noise Gaussian dengan signal-to-noise ratio (SNR) sebesar $10 \mathrm{~dB}$, yang ditambahkan pada model sumber sinyal.

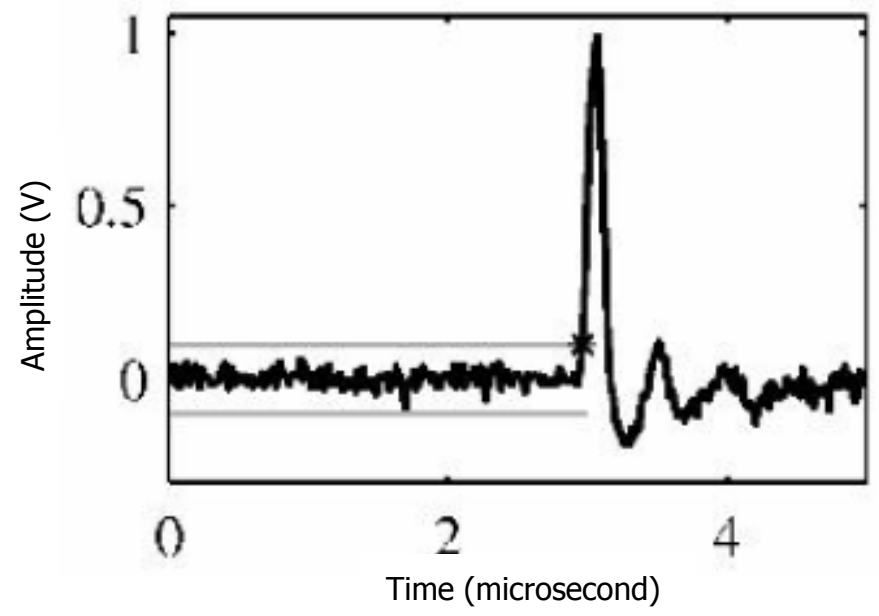

Gambar 6. Contoh sinyal PD dengan mengaplikasikan metoda Threshold Detection untuk menentukan TOA (Wagenaars, 2008)

Gambar 6 menunjukkan hubungan antara sinyal PD (kurva yang berwarna hitam) dan nilai ambang batas (kurva yang berwarna abu-abu) yang didapatkan dari hasil persamaan (11). Tanda * pada Gambar 6 menunjukkan waktu (time) saat pertama kali nilai amplituda sinyal PD mulai melebihi nilai ambang batas, yang diambil sebagai nilai TOA.

\section{Metode Peak Detection}

Metode ini digunakan untuk memperkirakan TOA dengan mendeteksi waktu saat gelombang sinyal yang diterima bernilai maksimum. 


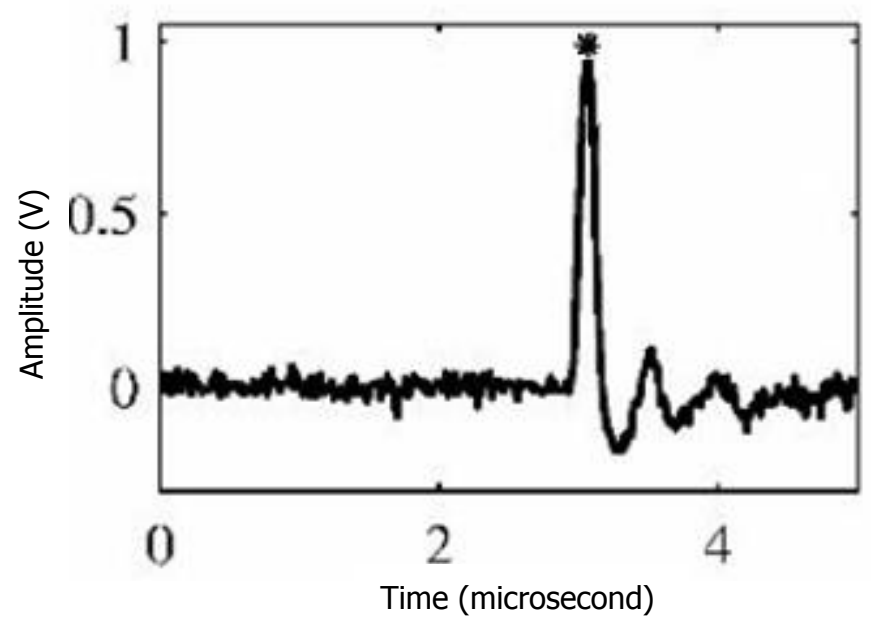

Gambar 7. Contoh sinyal PD dengan mengaplikasikan metoda Peak Detection untuk menentukan TOA (Wagenaars, 2008)

Gambar 7 menunjukkan bahwa waktu (time) saat nilai amplituda sinyal PD bernilai maksimum, itulah yang diambil sebagai nilai TOA (ditandai dengan tanda * pada kurva EC).

\section{Metode Cross Correlation}

Sinyal yang diterima pada dua antena yang terpisah secara spasial, dapat dimodelkan dengan persamaan matematis sebagai berikut:

$$
\begin{gathered}
s_{1}(t)=S(t)+n_{1}(t) \\
s_{2}(t)=\alpha S\left(t-\Delta t_{21}\right)+n_{2}(t)
\end{gathered}
$$

Dimana $S(t)$ adalah sumber sinyal impulsif yang asli, $n_{1}(t)$ dan $n_{2}(t)$ adalah sumber noise tambahan yang tidak saling berkorelasi dan memiliki zero mean values, $a$ adalah faktor redaman, dan $\Delta t_{21}$ adalah TDOA antar sinyal yang diterima. Ukuran kesamaan antara sepasang sinyal energi, $s_{1}(t)$ dan $s_{2}(t)$, dapat didefinisikan oleh urutan cross correlation $r_{s 1 s 2}(t)$, yang didefinisikan dalam persamaan berikut:

$$
r_{s_{1} s_{2}}(\Delta t)=\int_{-\infty}^{\infty} s_{1}(t) s_{2}\left(t-\Delta t_{21}\right) \cdot d \Delta t
$$

$\Delta t$ disebut time-lag dan menunjukkan pergeseran waktu antara pasangan sinyal. Metode cross correlation ini digunakan untuk memperkirakan time delay dengan mendeteksi waktu saat fungsi tersebut bernilai maksimal. Time lag yang memberikan nilai maksimum pada fungsi cross correlation adalah TDOA yang diperkirakan. 


\section{HASIL PENELITIAN DAN ANALISIS}

Pada penelitian ini digunakan satu buah laptop yaitu:

1. Tipe : Notebook

2. Prosesor : $2.0 \mathrm{GHz}$ Intel Core 2 Duo $\mathrm{T} 6400$

3. Memori : 2 GB DDR2

4. Media Storage : Western Digital $160 \mathrm{~GB}$

5. Operating System : Windows XP Service Pack 3

Dalam simulasi ini, digunakan empat buah antena dengan koordinat antena $1[0,0,1]$, antena $2[0,2,1]$, antena $3[-\sqrt{3},-1,1]$, dan antena $4[\sqrt{3},-1,1]$ (untuk jarak antar antena $d=$ $2 \mathrm{~m})$, serta satu sumber noise dengan koordinat $[10,10,1]$. Susunan antena membentuk huruf Y, seperti pada Gambar 8.

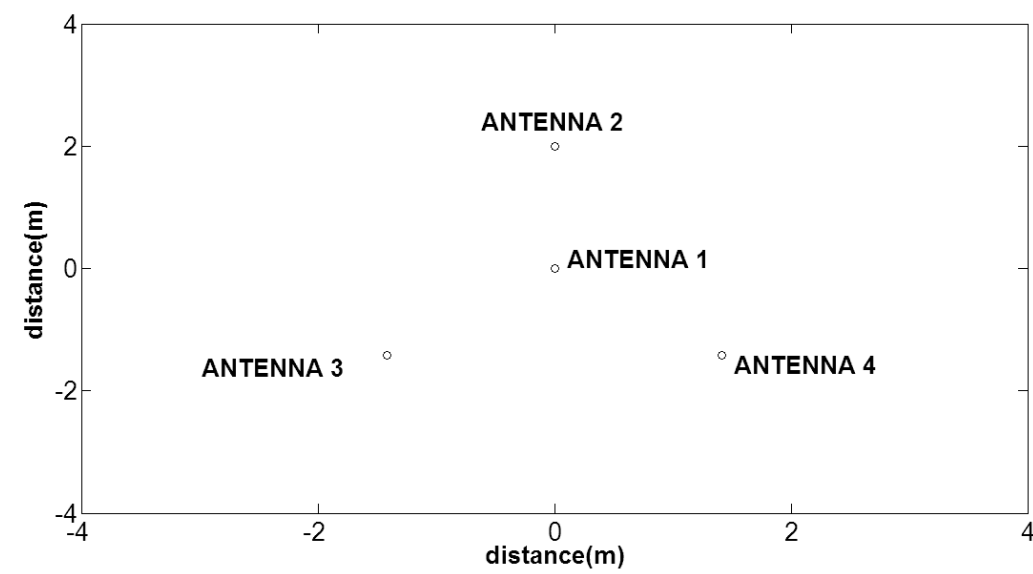

Gambar 8. Susunan antena membentuk $Y$ dengan jarak antar antena $d=2$ meter

Dilakukan juga simulasi dengan jarak antar antena $d=4$ meter. Pengujian dilakukan dengan melakukan pengambilan sampel sinyal sumber noise sebanyak 100 kali. Noise Gaussian dengan signal-to-noise ratio (SNR) sebesar $10 \mathrm{~dB}$ ditambahkan pada sinyal sumber noise.

Gambar 9 menunjukkan sinyal yang diterimas masing-masing antena, dimana Gambar 9(a) menggunakan konfigurasi susunan antena membentuk $Y$ dengan jarak antar antena $d=2$ meter, dan Gambar 9(b) menggunakan konfigurasi susunan antena membentuk $Y$ dengan jarak antar antena $d=4$ meter.

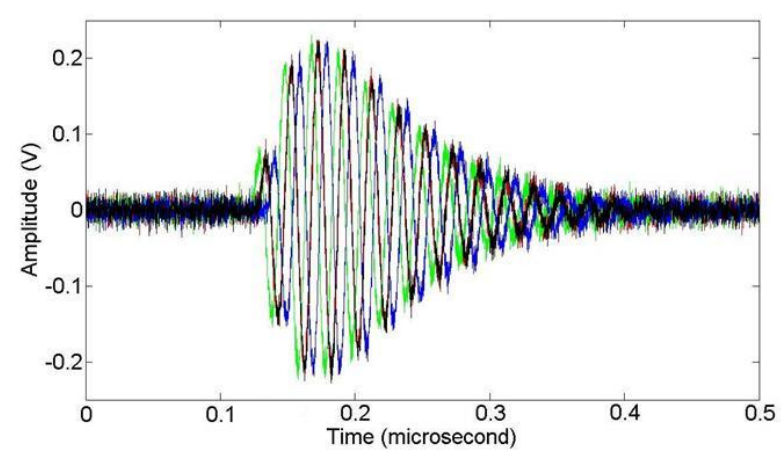

(a)

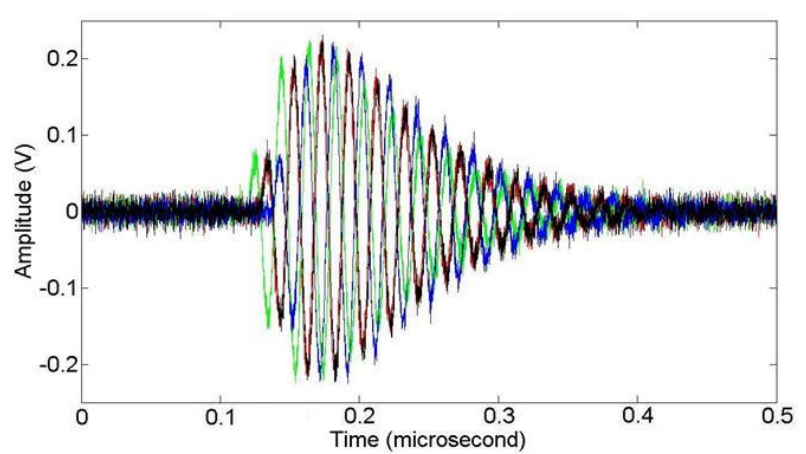

(b)

Gambar 9. Sinyal dari sumber noise yang diterima masing-masing antena dengan jarak antar antena: (a) $d=\mathbf{2}$ meter, (b) $d=\mathbf{4}$ meter 
Gambar 10 menunjukkan $\mathrm{TDOA}_{12}$, $\mathrm{TDOA}_{13}$, dan $\mathrm{TDOA}_{14}$ yang didapatkan dari hasil pengambilan sampel sinyal sumber noise sebanyak 100 kali, dimana Gambar 10(a) merupakan $\mathrm{TDOA}_{12}, \mathrm{TDOA}_{13}$, dan $\mathrm{TDOA}_{14}$ untuk jarak antar antena $d=2$ meter, dan Gambar 10(b) merupakan $\mathrm{TDOA}_{12}, \mathrm{TDOA}_{13}$, dan $\mathrm{TDOA}_{14}$ untuk jarak antar antena $d=4$ meter.

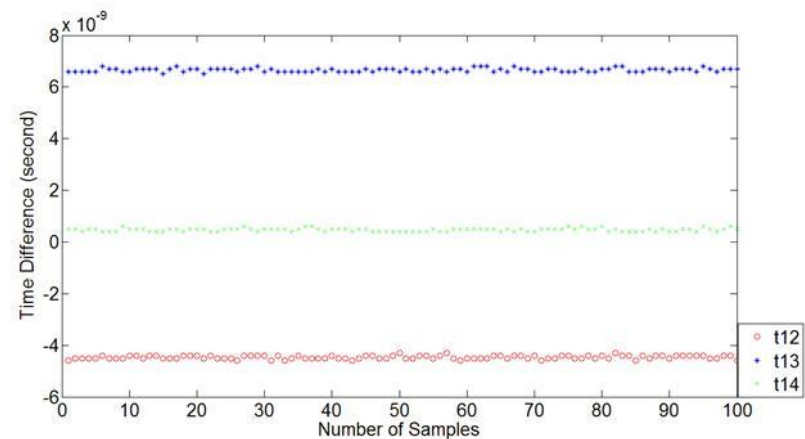

(a)

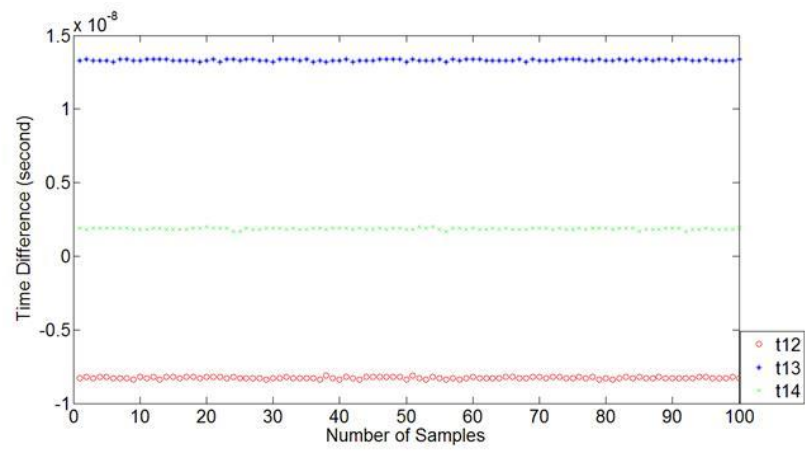

(b)

Gambar 10. TDOA antar antena (antena 1 sebagai antena referensi), hasil perhitungan metode cross-correlation, dengan jarak antar antena: (a) $d=\mathbf{2}$ meter, (b) $d=4$ meter

Gambar 11 menunjukkan estimasi lokasi sumber noise, hasil dari persamaan (1), (2), dan (3), dimana Gambar 11(a) merupakan hasil estimasi lokasi sumber noise dengan jarak antar antena $d=2$ meter, dan Gambar 11(b) merupakan hasil estimasi lokasi sumber noise

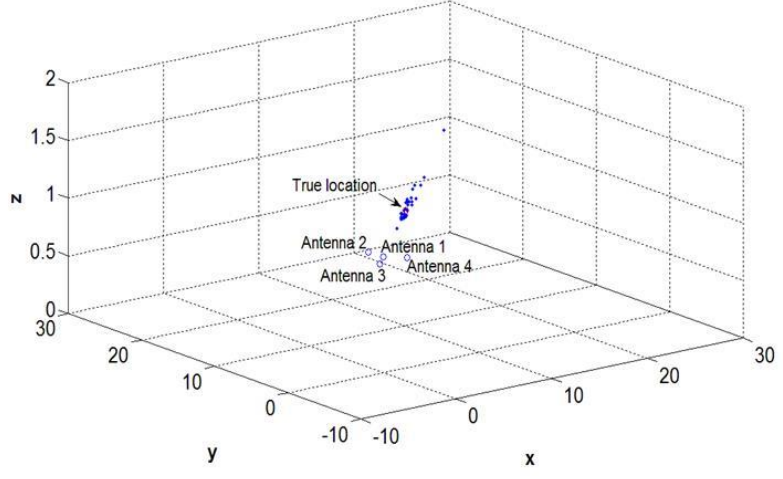

(a) dengan jarak antar antena $d=4$ meter.

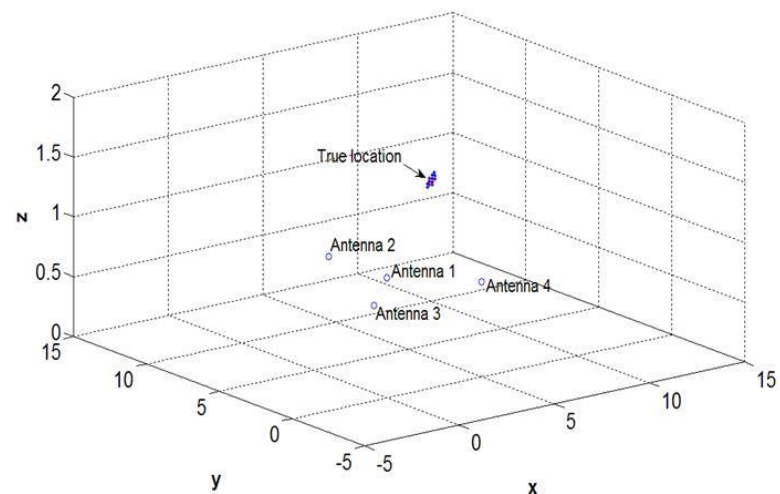

(b)

Gambar 11. Hasil estimasi lokasi sumber noise, menggunakan metode cross-correlation, dengan jarak antar antena: (a) $d=2$ meter, (b) $d=4$ meter

Berikut adalah tabel nilai ideal TDOA untuk jarak antar antena $d=2$ meter dan $d=4$ meter.

Tabel 2. Nilai TDOA ideal

\begin{tabular}{|c|c|c|c|}
\hline $\boldsymbol{d}(\mathbf{m})$ & $\boldsymbol{t 1 2}(\mathbf{n s})$ & $\boldsymbol{t 1 3}(\mathbf{n s})$ & $\boldsymbol{t 1 4}(\mathbf{n s})$ \\
\hline 2 & -4.45 & 6.67 & 0.47 \\
\hline 4 & -8.27 & 13.33 & 1.85 \\
\hline
\end{tabular}

Dari hasil pengujian, terlihat pada Gambar 10 bahwa tiap metode menghasilkan nilai TDOA yang berbeda-beda namun mendekati nilai TDOA ideal. Berikut adalah tabel nilai rata-rata dan standar deviasi TDOA dari tiap metode dengan jarak antar antena $d=2$ meter dan $d=$ 4 meter. 
Tabel 3. Nilai mean TDOA tiap metode

\begin{tabular}{|c|c|c|c|c|c|c|c|}
\hline \multirow{2}{*}{$d(\mathrm{~m})$} & \multirow{2}{*}{$\overline{\boldsymbol{t}}$} & \multicolumn{6}{|c|}{ Metode } \\
\hline & & AIC & EC & Gabor & peak & threshold & cross-corr \\
\hline \multirow{3}{*}{2} & $t 12(n s)$ & -4.80 & -4.41 & -4.63 & -4.83 & -4.40 & -4.46 \\
\hline & $t 13$ (ns) & 5.75 & 6.69 & 6.67 & 6.38 & 6.68 & 6.66 \\
\hline & $t 14(n s)$ & 9.22 & 0.43 & 0.28 & 0.48 & 0.50 & 0.47 \\
\hline \multirow{3}{*}{4} & $t 12(n s)$ & -8.75 & -8.27 & -8.26 & -7.77 & -8.38 & -8.27 \\
\hline & $t 13(n s)$ & 14.14 & 13.37 & 13.39 & 13.43 & 13.31 & 13.33 \\
\hline & $t 14(n s)$ & 1.61 & 1.90 & 1.88 & 2.08 & 1.84 & 1.85 \\
\hline
\end{tabular}

Tabel 4. Nilai standar deviasi tiap metode untuk $d=2$ meter

\begin{tabular}{|c|c|c|c|c|c|c|}
\hline \multirow{2}{*}{ Parameter } & \multicolumn{7}{|c|}{ Metode } \\
\hline & AIC & EC & Gabor & peak & threshold & cross-corr \\
\hline$e_{x}(m)$ & 161.73 & 6.85 & 40.24 & 15.89 & 14.33 & 0.91 \\
\hline stdev $_{e_{x}}(m)$ & 382.83 & 11.49 & 104.25 & 36.21 & 27.35 & 1.25 \\
\hline$e_{y}(m)$ & 98.91 & 6.96 & 39.28 & 16.26 & 14.46 & 0.96 \\
\hline stdev $_{e_{y}}(m)$ & 210.79 & 11.67 & 93.73 & 35.67 & 27.35 & 1.31 \\
\hline$e_{z}(m)$ & 0 & 0 & 0 & 0 & 0 & 0 \\
\hline stdev $v_{e_{z}}(m)$ & 0 & 0 & 0 & 0 & 0 & 0 \\
\hline$e_{r}(m)$ & 193.27 & 9.77 & 56.63 & 22.56 & 20.37 & 1.31 \\
\hline stdev $v_{e_{r}}(m)$ & 423.36 & 16.37 & 3.43 & 49.58 & 38.65 & 1.81 \\
\hline
\end{tabular}

Tabel 5. Nilai standar deviasi tiap metode untuk $d=4$ meter

\begin{tabular}{|c|c|c|c|c|c|c|}
\hline \multirow{2}{*}{ Parameter } & \multicolumn{7}{|c|}{ Metode } \\
\cline { 2 - 7 } & AIC & EC & Gabor & peak & threshold & cross-corr \\
\hline$e_{x}(m)$ & 95.79 & 1.72 & 14.31 & 25.48 & 2.39 & 0.23 \\
\hline stdev $_{e_{x}}(m)$ & 228.08 & 2.22 & 28.89 & 216.25 & 3.12 & 0.28 \\
\hline$e_{y}(m)$ & 72.65 & 1.81 & 15.14 & 16.07 & 2.61 & 0.24 \\
\hline stdev $_{e_{y}}(m)$ & 198.96 & 2.34 & 30.65 & 121.67 & 3.54 & 0.31 \\
\hline$e_{z}(m)$ & 0.01 & 0 & 0 & 0 & 0 & 0 \\
\hline stdev $_{e_{z}}(m)$ & 0.11 & 0 & 0 & 0 & 0 & 0 \\
\hline$e_{r}(m)$ & 127.42 & 2.49 & 20.87 & 30.23 & 3.53 & 0.33 \\
\hline stdev $_{e_{r}}(m)$ & 299.41 & 3.22 & 1.66 & 248.06 & 4.71 & 0.41 \\
\hline
\end{tabular}

Keterangan :
1. $e_{x} \quad=$ nilai error pada koordinat $\mathrm{x}(\mathrm{m})$
2. stdev $_{e_{x}}=$ standar deviasi koordinat $\mathrm{x}(\mathrm{m})$
6. stdev $_{e_{z}}=$ standar deviasi koordinat $\mathrm{z}(\mathrm{m})$
3. $e_{y} \quad=$ nilai error pada koordinat $\mathrm{y}(\mathrm{m})$
7. $e_{r} \quad=$ nilai error pada jarak dari $(0,0,1)$ ke lokasi sumber noise $(\mathrm{m})$
4. stdev $_{e_{y}}=$ standar deviasi koordinat $\mathrm{y}(\mathrm{m})$
8. stdev $_{e_{r}}=$ standar deviasi pada jarak dari
5. $e_{z} \quad=$ nilai error pada koordinat $\mathrm{z}(\mathrm{m})$ $(0,0,1)$ ke lokasi sumber noise $(\mathrm{m})$ 
Pada Gambar 11, terlihat bahwa estimasi lokasi yang didapatkan menunjukkan beberapa titik yang jauh dari lokasi sumber noise yang sebenarnya. Hal ini disebabkan oleh faktor metode penentuan TDOA yang digunakan serta sifat divergensi dari persamaan Newton-Raphson untuk menentukan lokasi sumber noise.

Kemudian, kita dapat melihat dari Tabel 3 bahwa metode estimasi nilai TDOA yang paling mendekati nilai TDOA ideal adalah metode cross-correlation, dan susunan antena konfigurasi $\mathrm{d}=4$ meter lebih akurat dibandingkan dengan susunan antena konfigurasi $\mathrm{d}=2$ meter. Perlu diingat bahwa nilai tanda negatif pada nilai t12 menunjukkan bahwa sinyal yang diterima antena 2 datang terlebih dahulu dibandingkan dengan sinyal yang diterima antena 1

Dengan melihat Tabel 4 dan Tabel 5, maka metode yang paling baik adalah metode crosscorrelation untuk $d=4$ meter, dengan galat $0-0.33$ meter. Galat dan nilai error pada koordinat $\mathrm{z}$ adalah 0 meter. Hal ini menunjukkan tingkat akurasi yang baik untuk deteksi sumber noise yang sejajar dengan tinggi antena.

Dari Gambar 11, maka kita dapat menentukan tingkat akurasi dengan tahapan sebagai berikut:

1. Mencari nilai error $(\varepsilon)$ untuk tiap pencuplikan, dengan $\varepsilon=\left(\left|r-r_{\text {true }}\right|\right) / r_{\text {true }} . r_{\text {true }}$ adalah jarak dari lokasi $(0,0,1)$ ke lokasi sumber noise yang sebenarnya $(P=$ $[10,10,1]$ meter).

2. Menjumlahkan semua nilai $\varepsilon$ tersebut, lalu membaginya dengan jumlah pencuplikan yang dilakukan (ini adalah nilai $\varepsilon$ rata-rata).

3. Dengan memasukkan nilai $\varepsilon$ rata-rata yang didapatkan, ke dalam rumus efisiensi ( $\eta$ $=1-\varepsilon$ ), maka didapatkan nilai tingkat akurasi sebesar $97.67 \%$.

Tingkat akurasi yang didapatkan dengan susunan antena membentuk Y (97.67\%) lebih besar dari penelitian sebelumnya yang menggunakan susunan antena membentuk persegi (95.87\%) (Ibrahim, 2014).

\section{KESIMPULAN}

Dari pengujian dan analisis simulasi yang telah dilakukan, dapat ditarik beberapa kesimpulan, yaitu:

1. Metode TDOA cukup efektif digunakan untuk pendeteksian sumber noise, dengan tingkat akurasi $97.67 \%$.

2. Dari beberapa metode yang digunakan untuk menentukan nilai TDOA, metode yang memiliki tingkat akurasi $97.67 \%$ adalah metoda cross-correlation dengan galat 0 0.33 meter.

3. Tingkat akurasi estimasi lokasi sumber noise akan lebih baik untuk deteksi sumber noise yang sejajar dengan tinggi antena, karena nilai error untuk koordinat sumbu $\mathrm{z}$ (jarak sumber noise dari permukaan bumi) adalah 0 .

4. Susunan antena membentuk $Y$ memiliki tingkat akurasi yang lebih tinggi $(97.67 \%)$ dibandingkan dengan susunan antena membentuk persegi $(95.87 \%)$. 
Pendeteksian Lokasi Sumber Noise (Partial Discharge) secara Tiga Dimensi Menggunakan Antenna Array

\section{DAFTAR RUJUKAN}

Kreuger, F. H. (1964). Discharge Detection in High Voltage Equipment. London: Temple Press.

Steiner, J. P., Reynolds, P. H., and Weeks, W. L. (1992). Estimating the location of partial discharges in cables: IEEE Trans. Electr. Insul., vol. 27, no. 1, pp. 44-59.

Quak, B., Gulski, E., Wester, F. J., and Seitz, P. N. (2003). Advanced PD site location in distribution power cables: Proc. 7th Int. Conf. Properties and Applications of Dielectric Materials, vol. 1, pp. 183-186.

Mashikian, M. S. (2002). Preventive maintenance testing of shielded power cable systems: IEEE Trans. Ind. Appl., vol. 38, no. 3, pp. 736-743.

Knapp, C. H., and Carter, G. C. (1976). The generalized correlation method for estimation of time delay: IEEE Trans. on Acoustic, Speech, Signal Processing, Vol. 24, No. 4, 320327.

Challa, R. N., and Shamsunder, S. (1998). Passive near-field localization of multiple nonGaussian sources in 3-D using cumulates: Signal Proc., Vol. 65, 39-53.

Tungkanawanich, A., Kawasaki, Z., and Matsuura, K. (2001). Analysis of VHF-wideband impulsive electromagnetic noises on power distribution lines: Trans. IEE Japan, Vol. $120-B$, No. $11,1538-1544$.

Cavallini, A., et al. (2003). A new approach to the diagnosis of solid insulation systems based on PD signal inference: IEEE Electr. Insul. Mag., vol. 19, no. 2, pp. 23-30.

Oussalah, N., Zebboudj, Y., and Boggs, S. A. (2007). Partial Discharge Pulse Propagation in Shielded Power Cable and Implications for Detection Sensitivity: IEEE Trans. Electr. Insul., vol. 23, no.6, pp. 5-10.

Wagenaars, P., Wouters, P.A.A.F., Wielen, P.J.C.M van der, and Steennis, E.F. (2008). Algorithms for Arrival Time Estimation of Partial Discharge Pulses in Cable Systems. Vancouver: ISEI.

Mardiana R., and Kawasaki, Z. (2000). Broadband Radio Interferometer Utilizing a Sequential Triggering Technique for Locating Fast-Moving Electromagnetic Sources Emitted from Lightning: IEEE Transactions on Instrumentation and Measurement, vol. 49, No.2.

Ibrahim, Nur. (2014). 3D Localization Technique for Broad Band Impulsive Noise Source. Bandung: IC3INA. 